\title{
Klausula Terkait Perlindungan terhadap Buruh Migran dan Urgensinya untuk Diatur Secara Khusus di dalam Perjanjian Perdagangan Bebas antara ASEAN dan Uni Eropa
}

\author{
Dodik Setiawan Nur Heriyanto \\ Fakultas Hukum Universitas Islam Indonesia \\ Jl. Tamansiswa No. 158 Yogyakarta \\ dodiksetiawan@uii.ac.id
}

\begin{abstract}
Economic globalization encourages some individuals to move abroad for a better living and livelihod. Currently, it is undeniable that the existence of foreign migrant workers can support the economic sutainability of European Union. However, foreign migrant workers mostly coming from ASEAN countries are only provided with limited social protection. Therefore, the research problems of this study are, first, whether the European Union rules have provided social protection for foreign migrant workers working around the territory or not? Second, what does ASEAN has to do in order to carry out its obligation to protect its citizens working outside ASEAN, especially within the framework of the agreement plan Free Trade Agreement between ASEAN and the EU? The research is conducted with normative method. The results of this study revealed two essential things: first, the rules in the European Union have not provided adequate protection for migrant workers of non-EU, especially for those coming from ASEAN countries. Secondly, there is the possibility for the inclusion of specific provisions related to social protection of migrant workers in the Free Trade Agreement between ASEAN and the EU.
\end{abstract}

Keywords: Migrant workers, social protection, ASEAN, EU, and the free trade agreement.

\begin{abstract}
Abstrak
Globalisasi ekonomi mendorong sebagian individu untuk bergerak di luar wilayah negara mereka untuk mendapatkan kehidupan dan pekerjaan yang lebih baik. Saat ini, Uni Eropa tidak dapat memungkiri terhadap keberadaan buruh migran yang berasal dari warga negara non-Uni Eropa untuk mendukung keberlangsungan ekonomi mereka. Namun, buruh migran non-Uni Eropa terutama dari ASEAN memperoleh perlindungan sosial yang terbatas. Rumusan masalah dalam penelitian ini, pertama, apakah peraturan yang terdapat di Uni Eropa sudah memberikan dukungan perlindungan sosial bagi tenaga kerja migran yang bekerja di wilayahnya? Kedua, upaya apa yang dapat dilakukan ASEAN untuk menunaikan kewajibannya melindungi warga negaranya yang bekerja di luar ASEAN khususnya dalam rangka rencana kesepakatan terhadap Perjanjian Perdagangan Bebas antara ASEAN dan Uni Eropa? Metode penelitian yang digunakan dalam penelitian ini adalah yuridis normatif. Hasil penelitian ini menyimpulkan dua hal penting: pertama, peraturan di Uni Eropa belum memberikan perlindungan yang cukup terhadap buruh migran non-Uni Eropa khususnya bagi mereka yang merupakan warga negara dari negara-negara ASEAN. Kedua, terdapat kemungkinan untuk dimasukkannya ketentuan khusus terkait dengan perlindungan sosial pekerja migran di dalam Perjanjian Perdagangan Bebas antara ASEAN dan Uni Eropa.
\end{abstract}

Kata kunci : Buruh migran, perlindungan sosial, ASEAN, Uni Eropa, dan perjanjian perdagangan bebas. 


\section{Pendahuluan}

Era globalisasi dan cepatnya pertumbuhan pasar dunia mempengaruhi pergerakan tenaga kerja antar negara. 'Perpindahan ke luar dari wilayah negara dimana mereka berasal'1 yang dilakukan oleh buruh migran pada dasarnya didorong oleh motif ekonomi semata-mata untuk mendapatkan kondisi pekerjaan yang terbaik dan penghidupan yang layak. Dari sisi makro ekonomi, buruh migran diposisikan sebagai agen perubahan yang berkontribusi secara langsung terhadap perkembangan ekonomi dan sosial negara dimana mereka bekerja dan juga menambah devisa negara dimana mereka berasal.

Di era abad 21 yang ditandai dengan munculnya integrasi pasar melalui organisasi regional, kebebasan perpindahan tenaga kerja menjadi isu signifikan dalam unifikasi pasar. Kebebasan perpindahan tenaga kerja (free movement of worker) di Uni Eropa sudah menjadi kisah sukses dimana dimensi ekonomi dan sosial dalam pasar tenaga kerja menjadi hal mendasar yang diatur dalam perjanjian integrasi Uni Eropa. ${ }^{2}$ Meski muncul permasalahan seperti dalam kasus Schmidberger ${ }^{3}$, Laval ${ }^{4}$, Viking 5 , and Omega 6 yang menggambarkan kontradiksi antara isu ekonomi dan sosial dalam implementasi prinsip kebebasan perpindahan tenaga kerja, akan tetapi Mahkamah Uni Eropa (European Court of Justice / ECJ) selalu mencoba untuk menyeimbangkan antara dimensi ekonomi dan sosial dalam isu ketenagakerjaan melalui putusan-putusannya. ${ }^{7}$

Tidak kalah dengan Uni Eropa, ASEAN juga menempatkan kebebasan perpindahan tenaga kerja di wilayah regionalnya sebagai salah satu pilar pokok untuk mendukung integrasi ekonomi. Hal ini tertuang dalam empat pilar pokok

${ }^{1}$ Buruh migran memiliki definisi sebagai seseorang yang mana akan, sedang, atau telah terlibat dalam suatu pekerjaan yang dibayar/digaji di suatu negara dimana bukan merupakan negara dimana dia berasal (atau memiliki kewarganegaraan). Lihat International Convention on the Protection on the Rights of All Migrant Workers and Members of Their Families, General Assembly Resolution 45/158, 18 Desember 1990, Pasal 2 (1).

2 M. Rönnmar, "Laval returns to Sweden: The Final Judgment of the Swedish Labour Court and Swedish Legislative Reforms”, 39 Industrial Law Journal 280, 2010, hlm. 280-282.

${ }^{3}$ Kasus C-112/00, Schmidberger (2003) ECR, hlm. I-5659.

${ }^{4}$ Kasus C-341/05, laval un Partneri Svenska byggnadsarbetareförbundet (2007) ECR, hlm. I-11767.

${ }^{5}$ Kasus C-438/05, International Transport Workers' Federation v Viking (2007) ECR, hlm. I-10779.

${ }^{6}$ Kasus C-36/02, Omega Spielhallen- und Automatenaufstellungs- GmbH v Oberbürgermeisterin des bundesstadt bonn (2004) ECR, hlm. I-9609.

${ }^{7}$ Hasil wawancara dengan hakim (Professor Endre Juhász) dan staf ahli di Mahkamah Uni Eropa (ECJ), Luxembourg pada tanggal 21 April 2015. Sybe A. de Vries, "Balancing Fundamental Rights with Economic Freedoms According to the European Court of Justice", 9 (1) Utrecht Law Review 169, 2013, hlm.169-170. 
kebijakan Masyarakat Ekonomi ASEAN (ASEAN Economic Community/MEA), yaitu: (a) sebagai pasar tunggal dan basis produksi internasional dengan memberikan kebebasan pergerakan barang, jasa, investasi, modal, dan tenaga kerja berpengalaman; (b) sebagai kawasan dengan daya saing ekonomi yang kompetitif; (c) sebagai kawasan dengan perkembangan ekonomi yang merata; dan (d) sebagai kawasan yang terintegrasi dengan perekonomian dunia. ${ }^{8}$

Jauh sebelum kebijakan MEA, telah terdapat arus perpindahan manusia (migrasi) dari kawasan ASEAN menuju negara berkembang dan negara maju khususnya di negara anggota Uni Eropa. Sebagai contoh berdasarkan statistik 6,7\% populasi migran di Jerman merupakan warganegara ASEAN dan Afrika. ${ }^{9}$ Inggris memberikan estimasi migran dari non-Uni Eropa akan bertambah banyak setiap tahun..$^{10}$ Data di tahun 2002 menunjukkan terdapat sejumlah 68 orang buruh migran asal Indonesia yang bekerja di Uni Eropa ${ }^{11}$, namun angka ini menjadi besar jika buruh migran ilegal (tanpa dokumen ketenagakerjaan yang lengkap dan sah) turut dihitung ${ }^{12}$. Sedangkan data online Eurostat (2013) mengungkapkan bahwa warga non-Uni Eropa yang berada di 27 negara anggota Uni Eropa berjumlah 20,7 juta jiwa di awal 2012 dan sekitar 22 persen berasal dari Asia khususnya Asia Tenggara dan Asia Timur. ${ }^{13}$ Meskipun prosentase keberadaan populasi non-Uni Eropa tersebut tidak merinci tujuan dan alasan migrasi, namun dari prosentase tersebut tentu dapat ditemukan alasan migrasi dengan tujuan untuk mendapatkan pekerjaan dan upah yang layak di negara-negara Uni Eropa.

${ }^{8}$ Declaration on the ASEAN Economic Community Blueprint, diadopsi di Singapura pada tanggal 20 November 2007.

${ }_{9}$ Anna Myunghee Kim, "Foreign Labour Migration and the Economic Crisis in the EU: Ongoing and Remaining Issues of the Migrant Workforce in Germany", Institute for the Study of Labour Discussion Paper Series No.1534, 2010, hlm. 9.

${ }^{10}$ Nametalkam, , "UK Limits Entry for Nigerians", bttp://wnw.gistmania.com/talk/topic,40680.0.html, diakses tanggal 17 Mei 2015.

11 Komnas Perempuan (Komisi Nasional Anti Kekerasan) terhadap Perempuan dan Solidaritas Perempuan/CARAM Indonesia, Buruh Migran Pekerja Rumab Tangga (TKW-PRT) Indonesia: Kerentanan dan InistiatifInisiatif Baru untuk Perlindungan Hak. Asasi TKW-PRT, Ford Foundation dan DGIS, 2003, hlm. 13.

12 Studi yang dilakukan oleh Gusnelly menunjukkan bahwa di Belanda khususnya di kota Amsterdam dan Rotterdam banyak didapati buruh migran asal Indonesia yang tanpa dilengkapi dokumen ketenagakerjaan yang sah dan tinggal antara 2 (dua) hingga 4 (empat) tahun untuk bekerja. Gusnelly, "Trend Issues Indonesian Labor Migration in the Netherlands", https:// wmw.academia.edu/3441735/TREND ISSUES INDONESIAN LABOR MIGRATION IN THE NETHERLANDS, diakses tanggal 12 April 2015.

13 Eurostat, "European social statistics pocketbook: All social statistics on the $\mathrm{EU}$ in one publication", bttp:// epp.eurostat.ec.europa.eu/cache/ITY PUBLIC/3-17072013-BP/EN/3- 17072013-BP-EN.PDF, diakses tanggal 12 April 2015. 
Di Uni Eropa, para buruh migran tidak memiliki hak yang sama dengan para tenaga kerja yang berasal dari negara-negara anggota Uni Eropa. Aturan Uni Eropa hanya memberikan jaminan perlindungan perpindahan tenaga kerja bagi warga negaranya dan setiap negara-negara anggota Uni Eropa wajib untuk memberikan jaminan perlindungan sosial dan ekonomi yang sama dengan tenaga kerja lokal. Sedangkan tenaga kerja dari luar wilayah Uni Eropa termasuk dari negara ASEAN hanya diberikan hak dan perlindungan terbatas.

Migrasi buruh migran dari ASEAN ke Uni Eropa menjadi fokus utama dalam penelitian ini. Keberadaan mereka harus mendapatkan perhatian serius khususnya bagi ASEAN yang saat ini tengah melakukan negosiasi Perjanjian Perdagangan Bebas (Free Trade Agreement) dengan Uni Eropa. Setidaknya akan banyak investor dari negara maju di Uni Eropa yang diuntungkan dengan perjanjian perdagangan bebas ini. Penelitian ini akan menganalisa aturan Uni Eropa terkait dengan perpindahan tenaga kerja antar negara anggota Uni Eropa. Hasil analisa tersebut akan tampak sejauh mana proteksi yang diberikan kepada tenaga kerja dari negaranegara ASEAN yang mengadu nasib di negara-negara Uni Eropa. Bagian selanjutnya dalam tulisan ini akan menjelaskan kemungkinan dimasukkannya klausula khusus terkait perlindungan buruh migran dari ASEAN di Uni Eropa ke dalam rancangan Perjanjian Perdagangan Bebas antara kedua organisasi regional tersebut.

\section{Rumusan Masalah}

Berdasarkan latar belakang di atas, tulisan ini akan menjawab dua persoalan utama terkait keberadaan tenaga kerja migran khususnya yang berasal dari ASEAN ke Uni Eropa, yaitu: pertama, apakah peraturan yang terdapat di Uni Eropa sudah memberikan dukungan perlindungan sosial bagi tenaga kerja migran yang bekerja di wilayahnya? Kedua, upaya apa yang dapat dilakukan ASEAN untuk menunaikan kewajibannya melindungi warga negaranya yang bekerja di luar ASEAN khususnya dalam rangka rencana kesepakatan terhadap Perjanjian Perdagangan Bebas antara ASEAN dan Uni Eropa? 


\section{Tujuan Penelitian}

Penelitian ini bertujuan untuk menganalisis perangkat hukum yang ada di Uni Eropa apakah telah proaktif terhadap perlindungan tenaga kerja migran yang menetap dan bekerja di wilayahnya. Selain itu, hasil dari analisa tersebut akan menjadi gambaran dasar untuk mencari upaya nyata yang dapat dilakukan oleh ASEAN untuk menunaikan kewajibannya melindungi warga negaranya yang bekerja di luar ASEAN khususnya dalam rangka dalam rangka rencana kesepakatan terhadap Perjanjian Perdagangan Bebas antara ASEAN dan Uni Eropa.

\section{Metode Penelitian}

Metode penelitian yang digunakan dalam studi ini adalah metode penelitian campuran (mixed methodology) ${ }^{14}$ dimana baik penelitian yuridis normatif maupun empiris meskipun memiliki pisau analisa yang berbeda tetapi dalam studi ini keduanya saling melengkapi satu sama lain. Secara yuridis normatif, seluruh aturan yang ada di Uni Eropa akan dikupas untuk mencari tahu letak kurangnya perlindungan yang diberikan kepada buruh migran di Uni Eropa. Sedangkan hasil pengamatan yang dilakukan oleh penulis secara empiris baik melalui studi lapangan dan wawancara menjadi bahan hukum pelengkap untuk mendukung argumentasi penulis terkait kemungkinan dimasukkannya klausula khusus terkait perlindungan tenaga kerja migran di dalam Perjanjian Perdagangan Bebas antara Uni Eropa dan ASEAN.

Angka-angka dan prosentase yang ada di dalam studi ini diperoleh penulis melalui studi lapangan di beberapa negara Uni Eropa dari 2014 hingga awal 2015. Selain itu, penulis juga berkesempatan untuk melakukan wawancara dengan hakim di Mahkamah Uni Eropa (European Court of Justice) dan Pengadilan Hak Asasi Manusia Eropa (European Court of Human Rights) serta staf yang membidangi hukum dan perlindungan tenaga kerja migran di beberapa institusi Uni Eropa.

14 Penelitian dengan metodologi campuran (mixed methodology) sangat jarang dilakukan peneliti namun sangat mungkin untuk dilakukan demi mendapatkan analisa yang lengkap dan kuat terhadap rumusan permasalahan dalam penelitian. Lihat John W. Creswell, Research Design: Qualitative, Quantitative, and Mixed Methods Approaches, SAGE Publications, California, 2014, hlm. 215-217. 
Untuk memberikan analisis hukum yang akurat, studi ini menggunakan bahan hukum baik primer maupun sekunder. Bahan hukum primer lebih diutamakan kepada aturan-aturan hukum di Uni Eropa khususnya terkait dengan perlindungan terhadap tenaga kerja migran. Sedangkan, pendapat hukum yang terkandung dalam putusan Mahkamah Uni Eropa serta dalam beberapa referensi pustaka menjadi bagian pelengkap untuk memberikan penjelasan tambahan terhadap bahan hukum primer. Keseluruhan bahan hukum beserta data empiris diolah secara kuantitatif ${ }^{15}$ sehingga diharapkan memberikan gambaran nyata kurangnya perlindungan terhadap tenaga kerja migran di Uni Eropa dan memberikan arahan sehingga penelitian ini dapat menjawab persoalan tersebut.

\section{Hasil Penelitian dan Pembahasan}

\section{Aturan Uni Eropa tentang Buruh Migran}

Sejak perpindahan tenaga kerja menjadi salah satu dari empat pilar integrasi ekonomi Uni Eropa, maka Pasal 45 Konstitusi Uni Eropa (Treaty on the Functioning of the European Union/TFEU) menjamin hak tenaga kerja secara bebas untuk mendapatkan pekerjaan di wilayah Uni Eropa. ${ }^{16}$ Tentu saja tenaga kerja disini merupakan tenaga kerja yang berasal dari negara-negara anggota Uni Eropa. Akan tetapi, dalam perjanjian tersebut tidak memberikan definisi jelas tentang apa yang dimaksud dengan kata 'tenaga kerja'. Catherine Barnard (2004) memberikan penjelasan bahwa 'tenaga kerja' dalam perjanjian ini melakukan hubungan kerja berdasarkan ketergantungan (subordinasi) dimana mereka berada di bawah kendali pemberi kerja (employer). ${ }^{17}$ Dalam kasus Allonby v. Accrington and Rossendale College, Mahkamah Uni Eropa menjelaskan bahwa ketiadaan definisi 'tenaga kerja' ini bukan tanpa sebab yaitu semata-mata agar tidak diinterpretasikan secara restriktif karena

${ }^{15}$ B. G. Glaser and A.L. Strauss, The Discovery of Grounded Theory: Strategies for Qualitative Research, Aldine Publishing Company, Chicago, 1967, hlm. 4-15.

16 Pasal 45 dalam TFEU mengatur: "(1) kebebasan bergerak setiap tenaga kerja harus dijamin oleh Uni Eropa; (2) Kebebasan tersebut harus meliputi penghapusan setiap diskriminasi berdasarkan kewarganegaraan antara tenaga kerja yang berasal dari negara anggota sehubungan dengan pekerjaan, renumerasi (upah), dan kondisi lainnya dalam lapangan kerja; (3) ...” The Treaty of the Functioning on the European Union (2012) OJ C326/65. 2004, hlm. 265.

17 Catherine Barnard, The Substantive Law of the EU, First Edition, Oxford University Press, London, 
memiliki makna luas yang dapat diterima oleh seluruh komunitas Uni Eropa. ${ }^{18}$ Jika terminologi 'tenaga kerja' dapat diatur dan ditafsirkan oleh pengadilan nasional, maka besar kemungkinan setiap negara anggota Uni Eropa akan memodifikasi dan memberikan limitasi terhadap perlindungan tenaga kerja yang bertentangan dengan tujuan utama komunitas Uni Eropa. ${ }^{19}$

Luasnya definisi tenaga kerja ini, pada dasarnya untuk menghindari pertentangan dengan landasan utama dari pengaturan kebebasan perpindahan tenaga kerja yang diatur dalam TFEU (Konstitusi Uni Eropa) yaitu diskriminasi atas dasar kewarganegaraan (untuk bekerja dimana saja di dalam wilayah Uni Eropa) adalah dilarang dan diskriminasi ini meliputi dalam hal perolehan pajak dan kesejahteraan sosial, akses terhadap lapangan pekerjaan, kondisi tempat bekerja, akses terhadap pelatihan kerja, keanggotaan dalam serikat kerja, perumahan, dan akses terhadap pendidikan anak. ${ }^{20}$

Jika dicermati secara lebih detail, TFEU tidak memberikan pengaturan jaminan perlindungan terhadap tenaga kerja non-Uni Eropa yang bekerja di negara-negara persatuan Uni Eropa. Hak dan kebebasan yang diatur dalam konstitusi Uni Eropa hanya berlaku untuk warga negara yang berasal dari negara Uni Eropa. Hanya warga non-Uni Eropa yang tinggal secara sah dan memiliki hubungan hukum dengan negara anggota Uni Eropa yang mendapatkan perlindungan sosial termasuk untuk keluarganya. ${ }^{21}$ Hubungan hukum yang dimaksud adalah jika para tenaga kerja nonUni Eropa melangsungkan pernikahan dengan warganegara Uni Eropa. ${ }^{22}$

${ }^{18}$ Damian Chalmers, et.al., European Union Law: Text and Materials, Cambridge University Press, London, 2014, hlm. 579-580.

${ }^{19}$ Untuk itu, hanya Mahkamah Uni Eropa yang berwenang untuk menafsirkan apakah legislasi negara anggota Uni Eropa bertentangan dengan luasnya definisi 'tenaga kerja' dan tujuan dasar jaminan kebebasan perpindahan tenaga kerja dalam TFEU. Kasus 75/63, Mrs. Hoekstra (née Unger) v. Bestuur der Cont. Bedrijfsvereniging voor Detailhandel en Ambachten (1964) ECR, hlm. 177. Dikutip dari Dorte Sindbjerg Martinsen, 'Who Has the Right to Intra-European Social Security? From Market Citizens to European Citizens and Beyond' dalam Russel A. Miller dan Peer Zumbansen, Annual of German and European Law, Berghahn Books, 2007, hlm. 219-220.

${ }^{20}$ Peraturan Parlemen (Parliament) dan Dewan (Counci) Uni Eropa No.492/2011 tanggal 5 April 2011 (2011) OJ L141/3. Dalam Pasal 7 paragraf 1 diatur "A worker who is a national of a Member State may not, in the territory of another Member State, be treated differently from national workers by reason of his nationality in respect of any conditions of employment and work, in particular as regards remuneration, dismissal, and, should he become unemployed, reinstatement or re-employment."

${ }^{21}$ Peraturan Parlemen dan Dewan Uni Eropa No. 883/2004 tanggal 29 April 2004 tentang Koordinasi Sistem Jaminan Sosial (2004) OJ L166. Aturan ini diamandemen melalui Peraturan Parlemen dan Dewan Uni Eropa No 987/2009 tanggal 16 September 2009 yang menambahkan pengaturan terkait prosedur pelaksanaan Peraturan No. $883 / 2004$.

22 Europol, "2011 EU Serious and Organized Crime Threat Assessment”, Chapter on Facilitated Illegal Immigration, https:// www.europol.europa.eu/sites/default/files/publications/octa2011.pdf, diakses tanggal 20 Mei 2015. 
Directive Dewan Uni Eropa 2011/98/EU yang dikenal dengan 'EU Blue Card Directive' memberikan peluang kepada tenaga kerja dari negara ketiga (non-EU) untuk mendapatkan status dan perlindungan sosial yang sama seperti tenaga kerja Uni Eropa dengan masa kerja satu hingga empat tahun dan dapat diperpanjang asalkan memenuhi persyaratan, antara lain: (1) mampu membuktikan bahwa mereka memiliki kualifikasi profesional yang tinggi atau masa kerja minimal 5 (lima) tahun di bidang pekerjaan yang relevan; (2) harus bekerja sebagai tenaga kerja yang dibayar dan bukan sebagai pengusaha atau self employed; (3) memiliki gaji kotor tahunan yang tinggi minimal 1,5 kali lipat dari rata-rata pendapatan nasional; (4) harus memiliki kontrak kerja yang mengikat minimal 1 (satu) tahun; (5) memiliki dokumen perjalanan yang lengkap dan sah; dan (6) harus memenuhi syarat hukum sesuai dengan standar dan aturan profesi tertentu. ${ }^{23}$ Aturan ini bersifat directive: negara Anggota Uni Eropa dapat memodifikasi dan mengatur secara berbeda selama tidak bertentangan dengan norma dasar Directive. Hal inilah yang menyebabkan perbedaan aturan antara negaranegara anggota Uni Eropa dan secara spesifik masih belum memberikan perlindungan secara equal kepada domestic worker (tenaga kerja rumahan) ${ }^{24}$ dan regular labor yang tidak masuk dalam kriteria Directive (seperti buruh pabrik). Terlebih lagi, Pasal 12 ayat (2) Directive juga membolehkan kepada negara anggota Uni Eropa untuk membatasi equal treatment (perlakuan yang sama) antara tenaga kerja dari Uni Eropa dan non-Uni Eropa. Sehingga pelaksanaan Directive ini menjadi kurang adil (unfair treatment) bagi tenaga kerja yang berasal dari non-Uni Eropa.

Banyak usaha telah dilakukan untuk mendorong negara anggota Uni Eropa untuk meratifikasi perjanjian hak asasi manusia internasional yang memberikan perlindungan kepada buruh migran tanpa syarat. Sejauh ini, berdasarkan hasil wawancara yang dilakukan oleh penulis dengan Dr. Péter Horvarth (hakim Pengadilan HAM Eropa (ECHR)25, belum terdapat negara anggota Uni Eropa yang

${ }^{23}$ Directive Parlemen dan Dewan Uni Eropa 2011/98/EU tanggal 13 Desember 2011 terkait prosedur aplikasi dan perijinan tunggal bagi warga negara pihak ketiga untuk bekerja dan tinggal di negara anggota Uni Eropa dan seperangkat hak yang diberikan kepada warga negara pihak ketiga yang tinggal secara sah di negara anggota Uni Eropa. Lihat European Commission, "Coming to the EU?", http://ec.europa.eu/immigration/tab1. do?subSec=29 \&language=7\$en\#higlyqual, di akses tanggal 20 Mei 2015.

${ }^{24}$ Kristin Carls, "Decent Work for Domestic Workers: the State of Labor Rights, Social Protection, and Trade Union Initiatives in Europe", https:// wmw.etuc.org/sites/wmw.etuc.org/files/Decent Work for Domestic Workers FINAL.pdf, diakses tanggal 20 Mei 2015.

${ }^{25}$ Wawancara dengan Dr. Péter Horvarth di Pengadilan HAM Eropa (ECHR), Strasbourg, Perancis, pada tanggal 22 April 2015. 
meratifikasi Convention on the Protection of the Rights of All Migrant Workers and Members of Their Families (Konvensi Perlindungan Hak-Hak Buruh Migran dan Anggota Keluarganya) dan hanya 6 (enam) negara anggota Uni Eropa (Perancis, Italia, Belanda, Portugal, Spanyol, dan Swedia) yang meratifikasi European Convention on the Legal Status of Migrant Workers (Konvensi Eropa tentang Status Hukum Buruh Migran). Berkaca dari kenyataan ini, Ban Ki-Moon menyampaikan kekecewaannya di hadapan Council of Europe (Dewan Eropa) terhadap minimnya ratifikasi yang dilakukan oleh negara-negara Eropa dan minimnya pelaksanaan norma-norma internasional perlindungan terhadap buruh migran:

"Here in Europe, ratification of the Convention on the Rights of Migrant Workers and their Families has been disappointing. Twenty years after it was adopted, none of Europe's largest and most wealthy powers have signed or ratified it. In some of the world's most advanced democracies ... among nations that take just pride in their long history of social progressiveness ... migrants are being denied basic human rights." 26

Berdasarkan pengamatan dan penelitian penulis selama di Eropa, minimnya kesadaran untuk meratifikasi dan melaksanakan perjanjian internasional oleh negara-negara Uni Eropa terkait buruh migran dilatarbelakangi dua alasan utama baik alasan ekonomi dan alasan sosial. Analogi umum yang sering dipakai untuk menghindari ratifikasi tersebut yaitu terpusat pada penghitungan biaya ekonomi dimana memberikan perlakuan yang sama antara tenaga kerja yang berasal dari Uni Eropa dan non-Uni Eropa membutuhkan alokasi biaya yang besar. Selain itu, tekanan sosial yang dihadapi juga tinggi mengingat kebanyakan buruh migran di negara Eropa Barat berasal dari negara Eropa Tengah dan Timur sehingga persaingan antara tenaga kerja Uni Eropa dan non-Uni Eropa dikhawatirkan akan menimbulkan gesekan-gesekan sosial.

\section{Perlindungan Buruh Migran ASEAN melalui Free Trade Agreement antara Uni Eropa dan ASEAN}

Sudah diterima sebagai kebiasaan umum internasional bahwa suatu negara yang berdaulat memiliki tanggung jawab penuh untuk melindungi warga negaranya

26 Council of Europe, "Speech by Ban Ki-Moon, Secretary-General of the United Nations", bttp:// www.coe.int/t/dc/press/news/20101019 speech ban ki moon EN.asp? Libat United Nations Human Rights Office of the High Commissioner, "Rights of Migrant Workers in Europe", http:/ / europe.ohchr.org/Documents/Publications/Migrant_Workers.pdf, hlm.15. Diakses tanggal 21 Mei 2015. 
baik di dalam maupun di luar negeri. Tanggung jawab untuk melindungi (responsibility to protect) merupakan suatu prinsip dasar dalam Hukum Internasional, meskipun hanya sedikit para sarjana yang mengakui penerapan tanggung jawab kolektif dalam konsep perlindungan di luar batas negara ${ }^{27}$ namun Resolusi Majelis Umum PBB memberikan penegasan bahwa tanggung jawab kolektif dapat dilaksanakan untuk memberikan perlindungan terhadap individu dalam payung hukum internasional. 28

Setiap negara memiliki kewajiban untuk melindungi buruh migran di dalam wilayahnya sebagai bagian dari perlindungan hak asasi manusia meskipun mereka bukan warga negaranya. Dalam praktek, hak buruh migran merupakan komponen inti dalam kebijakan imigrasi tenaga kerja yang diintegrasikan dalam hukum nasional suatu negara. Desain kebijakan migrasi tenaga kerja yang dibuat oleh negara umumnya menjawab tiga pertanyaan fundamental terkait dengan: (1) bagaimana mengatur jumlah buruh migran yang dapat diterima (misalnya berdasarkan skema kuota atau sistem poin (points based system)); (2) bagaimana memilih buruh migran (misalnya berdasarkan keahlian atau kewarganegaraan); dan (3) hak apa saja yang diberikan setelah mereka diterima bekerja (misalnya saja kebebasan memilih lapangan kerja, akses terhadap kesejahteraan, ijin tinggal baik sementara maupun permanen, akses terhadap kewarganegaraan, dan sebagainya). ${ }^{29}$

Realitanya, kebijakan integrasi ekonomi seringkali tidak memberikan perlindungan yang layak bagi tenaga kerja migran. Globalisasi memang mendorong individu untuk bergerak bebas kemana saja demi penghidupan yang layak namun globalisasi pasar memiliki sedikit atensi terhadap perlindungan sosial mereka. Prinsip teritorial,30 kadangkala dipakai untuk menjustifikasi pembatasan terhadap jaminan perlindungan sosial. Di Uni Eropa saja, sebagian besar tenaga kerja migran non-Uni Eropa belum mendapatkan perlindungan yang sama dengan tenaga kerja lokal dan bahkan dalam kasus tertentu sering

${ }^{27}$ Global Centre for the Responsibility to Protect, , "Implementing the Responsibility to Protect - The 2009 General Assembly Debate: An Assessment", http://globalr2p.org/media/pdf/GCR2P General Assembly Debate Assessment.pdf, diakses tanggal 22 Mei 2015.

28 GA Res 63/308, 14 September 2009, A/RES/63/308 (2009). Libat Luke Glanville, "The Responsibility to Protect Beyond Borders", 12 (1) Human Rights Law Review 1, 2012, hlm.14.

29 Martin Ruhs, "The Economics and Politics of Migrant Rights", https://mmw.compas.ox.ac.uk/ research/labourmarkets/the-economics-and-politics-of-migrant-rights/, diakses tanggal 22 Mei 2015.

30 Stefano Giubboni, Social Rights and Market Freedom in the European Constitution: A Labour Law Perspective, Cambridge University Press, 2006, hlm.82. 
ditemukan efek negatif yang berasal dari keluarga mereka yang turut tinggal bersama. ${ }^{31}$

Geopolitik perdagangan dunia saat ini mendorong negara-negara maju dan pelaku pasar dunia untuk mendapatkan partner dagang yang potensial mendongkrak angka pendapatan negara. Melalui kebijakan Masyarakat Ekonomi ASEAN yang akan diberlakukan di ujung 2015 menjadikan ASEAN menempati peringkat ke tujuh di dunia dengan perolehan GDP total secara keseluruhan sebesar 2,4 triliun USD di $2013^{32}$ dan diprediksikan menempati posisi keempat di dunia di 205033. Dengan total jumlah penduduk sebesar 600 juta jiwa, potensi pasar ASEAN lebih besar dari Uni Eropa dan memiliki ketersediaan tenaga kerja terbesar ketiga di dunia. ${ }^{34}$

Saat ini, ASEAN dianggap sebagai mitra dagang ketiga terbesar oleh Uni Eropa (setelah Amerika Serikat dan Cina) dengan lebih dari 235 bilyun Euro diperoleh melalui perdagangan barang dan jasa pada tahun 2012.35 Kita tidak dapat memungkiri pertumbuhan ekonomi kedua organisasi regional ini yang memicu kedekatan hubungan dagang yang saling menguntungkan diantara keduanya:

"Statistics bear testimony to the growing scale of commercial involvement. From 1990-1998, ASEAN exports to the EU trebled to reach some 45 billion Euros. .... In 2001, the EU was ASEAN's second largest export market and the third largest trading partner after the United States and Japan. EU exports to ASEAN were estimated at 42.2 billion Euros, while EU imports from ASEAN were valued at 65.7 billion Euros, demonstrating that EU maintained its commitment to keeping its market open to ASEAN after the 1997 Asian Financial Crisis...." 36

ASEAN dan Uni Eropa dalam beberapa tahun ini tengah melakukan diskusi intensif untuk membangun komitmen bersama untuk menerapkan perdagangan bebas diantara keduanya. Sebelumnya, Komisi Uni Eropa (European Commission) mengadopsi kebijakan Communication on a "New Partnership with

31 Janusz Bojarski, "Problems of Black Labour, Illegal Immigration, and Money Laundering in Poland", 10 (3) Journal of Money Laundering Control 367, 2007, hlm.367-378.

32 Stephen P. Groff, "Keynote Speech: ASEAN Integration and the Private Sector", bttp:// www.adb.org/news/ speeches/keynote-speech-asean-integration-and-private-sector-stephen-p-groff, diakses tanggal 21 Mei 2015.

33 Ibid. Lihat OECD, "Economic Outlook for Southeast Asia, China, and India 2014", http:// www.oecd.org/site/seao/Pocket\%20Edition\%20SAEO2014.pdf, diakses tanggal 21 Mei 2015.

${ }^{34}$ H. Hill and J Menon, 'ASEAN Economic Integration: Driven by Markets, Bureaucrats, or Both?', dalam M.E. Kreinin and M.G. Plummer (eds.), The Oxford Handbook of International Commercial Policy, Oxford University Press, Oxford, 2012, hlm. 357-386.

${ }^{35}$ Hasil dari wawancara dengan staf ahli Komisi Uni Eropa di Brussel, Belgia, 24 April 2015.

36 Paul J.J. Welfens, et.al., EU-ASEAN: Facing Economic Globalisation, Springer Science and Business Media, 2008, hlm. 69-70. 
South East Asia" di tahun 2003 untuk membuat langkah strategis dalam merekatkan hubungan dengan negara-negara di Asia Tenggara. ${ }^{37}$ Di 2012, antara Uni Eropa dan ASEAN telah menandatangani suatu kesepakatan rencana kerja dalam rentang waktu 5 (lima) tahun untuk menguatkan intensitas dialog salah satunya untuk mewujudkan kerjasama perdagangan bebas di antara keduanya. ${ }^{38}$ Meskipun hingga saat ini perjanjian perdagangan bebas dimaksud masih dalam proses negosiasi, namun ASEAN dapat mengajukan klausula khusus terkait perlindungan minimal terhadap tenaga kerja migran sebagai suatu syarat mutlak penandatanganan perjanjian tersebut.

Klausula perlindungan tenaga kerja merupakan bagian yang tidak dapat dipisahkan dengan tujuan utama perdagangan bebas. Justru pertumbuhan dan kemampuan pasar tenaga kerja menjadi faktor penting dalam perdagangan bebas, dan untuk itu keberadaannya perlu menjadi perhatian yang serius dalam negosiasi perjanjian perdagangan bebas. Kemudahan pergerakan investasi dalam perdagangan bebas tentu akan diikuti dengan kemudahan untuk menembus akses lapangan kerja. Terlebih lagi, isu terkait tenaga kerja seringkali menjadi perdebatan dalam perjanjian perdagangan bebas seperti dalam kesepakatan North American Free Trade Agreement (NAFTA) ${ }^{39}$ dan Perjanjian Perdagangan Bebas antara Cina dan Australia ${ }^{40}$.

Klausula perlindungan tenaga kerja migran dalam Perjanjian Perdagangan Bebas antara ASEAN dan Uni Eropa tentu harus mengandung prinsip dasar nondiskriminasi atau perlakuan yang sama antara tenaga kerja yang berasal dari Uni Eropa dan ASEAN. Prinsip ini penting untuk diterapkan dalam hubungan

37 European Commission, "A New Partnership with South East Asia: Communication from the Commission”, COM 399 Final, 2003. Lihat juga Chien-Huei Wu, 'A Mismatch Between Ambition and Reality: The EU's Efforts to Counterbalance China and the US in East Asia' dalam Christoph Hermann, et.al., European Yearbook of International Economic Law 2015, Springer, 2015, hlm.252.

38 Gauri Khandekar, "Mapping EU-ASEAN Relations", http://fride.org/descarga/Mapping EU ASEAN Relations.pdf, diakses tanggal 23 Mei 2015.

39 Tenaga kerja di Mexico mendapatkan upah lebih rendah dari Amerika Serikat. Kekhawatiran dari adanya kesepakatan NAFTA adalah pengurangan hambatan perdagangan dan investasi antara kedua negara akan mengurangi upah tenaga kerja di Amerika Serikat yang keahliannya dapat digantikan oleh tenaga kerja dari Mexico. The Congress of the United States, Congressional Budget Office, A Budgetary and Economic Analysis of the North American Free Trade Agreement, Washington DC, 1993, hlm. 85.

${ }^{40}$ Lihat Joanna Howe, "The Impact of the China-Australia Free Trade Agreement on Australian Job Opportunities, Wages, and Conditions",http://www.asu.asn.au/documents/doc_download/963-the-impact-of-the-chinaaustralia-free-trade-agreement-on-australian-job-opportunities-wages-and-conditions-by-dr-joanna-howe-october-2015.,diakses tanggal 24 Mei 2015. 
ketenagakerjaan era pasar bebas dan di Uni Eropa prinsip ini sangat dijunjung tinggi dalam pelaksanaanya seperti terlihat jelas dalam kasus Gottardo. ${ }^{41}$ Dalam kasus ini, Mahkamah Uni Eropa memutuskan bahwa jika negara anggota Uni Eropa melakukan kesepakatan bilateral dengan negara non-Uni Eropa (yang mana dalam kasus ini adalah antara Italia dan Swiss), maka prinsip dasar perlakuan yang sama (equal treatment) mensyaratkan negara anggota Uni Eropa (yang melakukan kesepakatan tersebut) harus memperlakukan warga negara anggota Uni Eropa lainnya sama seperti warga negaranya yang menikmati manfaat dari perjanjian tersebut. ${ }^{42}$

Dengan kedudukannya sebagai mitra dagang terbesar ketiga bagi Uni Eropa, ASEAN tentu dapat mengajukan proposal untuk menempatkan perlindungan tenaga kerja migran di dalam Perjanjian Perdagangan Bebas antara ASEAN dan Uni Eropa ke dalam ketentuan perjanjian. Klausula ini tentu memberikan proteksi sosial yang sama baik bagi tenaga kerja yang berasal dari ASEAN di Uni Eropa dan sebaliknya. Dengan adanya klausula khusus tersebut maka tanggung jawab untuk melindungi tenaga kerja dipikul secara bersama baik negara anggota ASEAN maupun Uni Eropa dan setiap perpindahan tenaga kerja dijamin hak dan perlindungan sosialnya. Sudah saatnya ASEAN menggunakan kedudukan geopolitiknya yang strategis untuk memperkuat perlindungan warga negaranya di luar wilayah ASEAN. Rezim perdagangan bebas memang tidak sepenuhnya sempurna karena dalam praktek efek sosial seringkali menjadi taruhan untuk kepentingan ekonomis, akan tetapi setidaknya kehadiran klausula ini dapat mengurangi aspek sosial khususnya terkait permasalahan buruh migran yang selalu berujung politis dan tidak adil.

\section{Penutup}

Di penghujung 2015, negara anggota ASEAN sepakat untuk menyatukan wilayahnya ke tahap integrasi ekonomi dengan dasar pasar tunggal dan basis produksi sebagaimana dikonseptualisasikan ke dalam Masyarakat Ekonomi

${ }^{41}$ Kasus C-55/00, Gottardo (2002) ECR, hlm. I-413.

42 Ibid. International Labour Organization, "Social Security Coordination for Non-EU Countries in South and Eastern Europe: A Legal Analysis", (http://www.ilo.org/wcmsp5/groups/public/---europe/---ro-geneva/---srobudapest/documents/publication/wcms_205316.pdf). 
ASEAN. Misi integrasi ekonomi yang ambisius ini seharusnya tidak mengesampingkan kenyataan bahwa terdapat perpindahan sejumlah tenaga kerja migran yang berasal dari ASEAN menuju Amerika Serikat, China, India, dan Uni Eropa demi penghidupan dan pekerjaan yang layak. Keberadaan mereka layak dipertimbangkan mengingat di satu sisi memberikan tambahan devisa negara asal namun di sisi lain negara memiliki tanggungjawab untuk memberikan perlindungan (responsibility to protect).

Sejumlah tenaga kerja migran asal ASEAN di Uni Eropa realitanya tidak semuanya mendapatkan perlindungan dan kesejahteraan sosial yang sama dengan warga lokal. Terlebih lagi belum ada negara anggota Uni Eropa yang merupakan peserta dari Konvensi Perlindungan Hak-Hak Buruh Migran dan Anggota Keluarganya dan baru 6 (enam) negara anggota Uni Eropa (Perancis, Italia, Belanda, Portugal, Spanyol, dan Swedia) yang meratifikasi Konvensi Eropa tentang Status Hukum Buruh Migran. Berkaca dari kondisi ini, ASEAN harus mempertegas posisinya untuk memberikan perlindungan bagi warganegaranya melalui negosiasi intensif perumusan kesepakataan perdagangan bebas yang sedang dilakukan antara ASEAN dan Uni Eropa. Sebagai mitra dagang terbesar ketiga Uni Eropa, ASEAN dapat menawarkan konsep perlindungan tenaga kerja migran baik dari ASEAN ke Uni Eropa dan sebaliknya ke dalam suatu rumusan klausula khusus di dalam perjanjian perdagangan bebas antara keduanya. Rumusan klausula ini haruslah cermat dengan menjunjung tinggi nilai-nilai hak asasi manusia dasar bagi tenaga kerja migran dan tidak melanggar prinsip non-diskriminasi. Hubungan dagang antara ASEAN dan Uni Eropa yang diimbangi dengan perlindungan sosial bagi tenaga kerja migran diantara keduanya akan menciptakan perdagangan yang sehat dan berkeadilan sehingga tujuan dasar kerjasama perdagangan dapat diraih dengan tanpa adanya distorsi sosial khususnya dalam bidang ketenagakerjaan.

\section{Daftar Pustaka}

\section{Buku}

Barnard, Catherine, The Substantive Law of the EU, First Edition, Oxford University Press, London, 2004. 
Chalmers, Damian, et.al., European Union Law: Text and Materials, Cambridge University Press, London, 2014.

Creswell, John W., Research Design: Qualitative, Quantitative, and Mixed Methods Approaches, SAGE Publications, California, 2014.

Giubboni, Stefano, Social Rights and Market Freedom in the European Constitution: A Labour Law Perspective, Cambridge University Press, 2006.

Christoph Hermann, et.al., European Yearbook of International Economic Law 2015, Springer, 2015.

Komnas Perempuan (Komisi Nasional Anti Kekerasan) terhadap Perempuan dan Solidaritas Perempuan/CARAM Indonesia, Buruh Migran Pekerja Rumah Tangga (TKW-PRT) Indonesia: Kerentanan dan Inistiatif-Inisiatif Baru untuk Perlindungan Hak Asasi TKW-PRT, Ford Foundation dan DGIS, 2003.

Kreinin, M.E. and Plummer, M.G. (eds.), The Oxford Handbook of International Commercial Policy, Oxford University Press, Oxford, 2012.

Miller, Russel A. dan Zumbansen, Peer, Annual of German and European Law, Berghahn Books, 2007.

The Congress of the United States, Congressional Budget Office, A Budgetary and Economic Analysis of the North American Free Trade Agreement, Washington DC, 1993.

Welfens, Paul J.J., et.al., EU-ASEAN: Facing Economic Globalisation, Springer Science and Business Media, 2008.

\section{Jurnal, Makalah, dan Laporan}

Bojarski, Janusz, "Problems of Black Labour, Illegal Immigration, and Money Laundering in Poland", 10 (3) Journal of Money Laundering Control 367, 2007.

de Vries, Sybe A., "Balancing Fundamental Rights with Economic Freedoms According to the European Court of Justice", 9 (1) Utrecht Law Review 169, 2013.

European Commission, "A New Partnership with South East Asia: Communication from the Commission", COM 399 Final, 2003.

Glanville, Luke, "The Responsibility to Protect Beyond Borders", 12 (1) Human Rights Law Review 1, 2012.

Kim, Anna Myunghee, "Foreign Labour Migration and the Economic Crisis in the EU: Ongoing and Remaining Issues of the Migrant Workforce in Germany", Institute for the Study of Labour Discussion Paper Series No.1534, 2010.

Rönnmar, M., "Laval returns to Sweden: The Final Judgment of the Swedish Labour Court and Swedish Legislative Reforms", 39 Industrial Law Journal 280, 2010. 


\section{Kasus}

Kasus 75/63, Mrs. Hoekstra (née Unger) v. Bestuur der Cont. Bedrijfsvereniging voor Detailhandel en Ambachten (1964) ECR.

Kasus C-55/00, Gottardo (2002) ECR.

Kasus C-112/00, Schmidberger (2003) ECR.

Kasus C-36/02, Omega Spielhallen- und Automatenaufstellungs- GmbH v Oberbü̈germeisterin des bundesstadt bonn (2004) ECR.

Kasus C-341/05, laval un Partneri Svenska byggnadsarbetarefö̈bundet (2007) ECR.

Kasus C-438/05, International Transport Workers' Federation v Viking (2007) ECR.

\section{Legislasi dan Perjanjian Internasional}

Perserikatan Bangsa-Bangsa (United Nations)

International Convention on the Protection on the Rights of All Migrant Workers and Members of Their Families, General Assembly Resolution 45/158, 18 Desember 1990.

GA Res 63/308, 14 September 2009, A/RES/63/308 (2009).

Uni Eropa (European Union)

Regulation (EC) No. 883/2004 of the European Parliament and of the Council of 29 April 2004 on the Coordination of Social Security Systems (2004) OJ L166.

Regulation (EU) No.492/2011 of the European Parliament and of the Council of 5 April 2011 (2011) OJ L141/3.

The Treaty of the Functioning on the European Union (2012) OJ C326/65.

ASEAN

Declaration on the ASEAN Economic Community Blueprint, adopted in Singapore on 20 November 2007.

\section{Lain-lain}

Carls, Kristin, "Decent Work for Domestic Workers: the State of Labor Rights, Social Protection, and Trade Union Initiatives in Europe", https://www.etuc.org/sites/www.etuc.org/files/Decent_Work_for_Domestic_Worke rs_FINAL.pdf, diakses tanggal 20 Mei 2015.

Council of Europe, "Speech by Ban Ki-Moon, Secretary-General of the United Nations",http://www.coe.int/t/dc/press/news/20101019_speech_ban_ki_moon_E N.asp?, diakses tanggal 21 Mei 2015. 
European Commission, "Coming to the EU?", http://ec.europa.eu/immigration/tab1.do?subSec=29\&language=7\$en\# higlyqual, diakses tanggal 20 Mei 2015.

Europol, "2011 EU Serious and Organized Crime Threat Assessment", Chapter on Facilitated Illegal Immigration, https://www.europol.europa.eu/sites/default/ files/publications/octa2011.pdf, diakses tanggal 20 Mei 2015.

Eurostat, "European social statistics pocketbook: All social statistics on the EU in one publication", http://epp.eurostat.ec.europa.eu/cache/ITY_PUBLIC/317072013-BP/EN/3- 17072013-BP-EN.PDF, diakses tanggal 12 April 2015.

Global Centre for the Responsibility to Protect, "Implementing the Responsibility to Protect - The 2009 General Assembly Debate: An Assessment", http://globalr2p.org/media/pdf/GCR2P_General_Assembly_Debate_Assessment.pd $f$, diakses tanggal 22 Mei 2015.

Groff, Stephen P., "Keynote Speech: ASEAN Integration and the Private Sector", http://www.adb.org/news/speeches/keynote-speech-asean-integration-and-privatesector-stephen-p-groff, diakses tanggal 21 Mei 2015.

Gusnelly, "Trend Issues Indonesian Labor Migration in the Netherlands", https://www.academia.edu/3441735/TREND_ISSUES_INDONESIAN_LABOR_ MIGRATION_IN_THE_NETHERLANDS, diakses tanggal 12 April 2015.

Howe, Joanna, "The Impact of the China-Australia Free Trade Agreement on Australian Job Opportunities, Wages, and Conditions", http://www.asu.asn.au/documents/doc_download/963-the-impact-of-the-chinaaustralia-free-trade-agreement-on-australian-job-opportunities-wages-andconditions-by-dr-joanna-howe-october-2015, diakses tanggal 24 Mei 2015.

International Labour Organization, "Social Security Coordination for Non-EU Countries in South and Eastern Europe: A Legal Analysis", (http://www.ilo.org/wcmsp5/groups/public/---europe/---ro-geneva/--sro-budapest/documents/publication/wcms_205316.pdf).

Khandekar, Gauri, "Mapping EU-ASEAN Relations", http://fride.org/descarga IMapping_EU_ASEAN_Relations.pdf, diakses tanggal 23 Mei 2015.

Nametalkam,“UK Limits Entry for Nigerians”, http://wwww.gistmania.com/talk/ topic,40680.0.html, diakses tanggal 17 Mei 2015.

OECD, "Economic Outlook for Southeast Asia, China, and India 2014", http://www.oecd.org/site/seao/Pocket\%20Edition\%20SAEO2014.pdf, diakses tanggal 21 Mei 2015.

Ruhs, Martin, "The Economics and Politics of Migrant Rights", https://www.compas.ox.ac.uk/research/labourmarkets/the-economics-and-politicsof-migrant-rights/, diakses tanggal 22 Mei 2015.

United Nations Human Rights Office of the High Commissioner, "Rights of Migrant Workers in Europe", ,http://europe.ohchr.org/Documents/Publications Migrant_Workers.pdf diakses tanggal 21 Mei 2015. 